\title{
The landscaping of Upper Silesia after 1989
}

\section{Alicja Kosterska}

(Institute of Polish Culture; University of Warsaw)

\begin{abstract}
:
The paper offers a critical analysis of the representations of post-industrial landscapes in Upper Silesia. It takes a look at the products of visual culture after 1989: feature films set in the region and photographs by Wojciech Wilczyk, trying to detect their embedded ideological mechanism and explain its dynamics. Drawing on the concepts advanced by Tim Edensor and W.J.T. Mitchell, the paper demonstrates that that mechanism consists in using aestheticization tools and sight cropping, following which a comprehensive view is feigned. As a result, Upper Silesia appears to be a degenerate space affected by permanent stagnation. In closing, the requirements that representations of landscape should meet are enumerated in order to provide insights into the diversity of a region, as well as offering a point of departure for reflection on its place in the national imagination. Ultimately, these considerations enable the expression of Upper Silesian identity from a position other than that of inferiority and subordination.
\end{abstract}

Key words:

landscape, ruin, Upper Silesia, Silesian film, post-industrial areas

"Is landscape the world we are living in, or a scene we are looking at, from afar?" (Wylie 2007, I), John Wylie wondered in the introduction to a book which offered a synthetic overview of positions and discussions concerning the category of landscape in contemporary cultural studies. At the same time, the researcher drew attention to one of the core tensions which have accompanied landscape studies since they emerged as an autonomous field of inquiry. The existing definitions of landscape are spread along an axis spanning two extremes: "Environment, space (area), nature, even reality and the thing itself are one side of the opposition; the other comprises notion, perception, phenomenon, representation, image (landscape)" (Zaremba 20I4b), as Łukasz Zaremba recapitulated, demonstrating, following Mateusz Salwa, that attempts to reconcile those seemingly incongruent standpoints tend to have fairly unfortunate outcomes, entailing the risk of losing the analytical potential of the term, as in the case of the legislative definition 
contained in the European Landscape Convention, where landscape is an "area, as perceived by people," in other words everything that surrounds us (Zaremba 20I4b, 7-8). Authors of theoretical interdisciplinary approaches try to circumvent such pitfalls, formulating their descriptions of landscape in such a way that it does not overlap at any point with the above opposition and simultaneously highlights the specificity of the phenomenon it seeks to encapsulate. 1

Even though this text does not aspire to redefine the category of landscape, reference to the above dilemma is not irrelevant, as it enables me to situate the cited case studies against the backdrop of approaches adopted in current research. In my analysis, I will be looking at cinematographic and photographic representations of Upper Silesia, which suggests greater affinity with the "visual" pole of the contradiction, although the representations will provide, to some degree, a negative frame of reference; I would like to examine them critically and consider the ideological mechanisms that they enact. I am primarily interested in depictions created after 1989, as in my opinion the date marks a turning point in perceptions of the region. Before 1989, Upper Silesia was seen more as a resource, its value calculated in the tons of coal that could be mined. In the wake of political and economic changes after 1989, the previously predominant land of Upper Silesia lost the utility value it had had, but its exchange value is still there: the capacity to participate in the exchange of ideas and cultural communication, enabling it to be revealed as a landscape. ${ }^{2}$ It is not without significance that the monolithic vision of the nation, hitherto propagated by the authorities of the Polish People's Republic, began to crumble gradually, at least to such an extent that regional difference can be articulated and confronted. Hence reflection on the representation of Upper Silesian space after 1989 appears to be an interesting issue for inquiry, as I believe that culturally shaped modes of perceiving landscapes have a direct impact on how we function in an environment or, in other words, the ways in which we tend to organize the visual field have their material outcomes in the formation of collective and individual identities.

\section{1.}

In the final, climactic scenes of Michał Rosa's 2006 Co stonko widziało (What the Sun Has Seen) the paths of three protagonists which until then have been followed separately finally converge. Sebastian, Marta, and Józef, all compelled to raise an

1 In Poland, particularly interesting conclusions in that respect have been drawn by Beata Frydryczak (2013) and Mateusz Salwa (2014, 43-54).

2 The difference between landscape and land was discussed by W. J.T. Mitchell: “The land, real property, contains a limited quantity of wealth in minerals, vegetation, water, and dwelling space. Dig out all the gold in a mountainside, and its wealth is exhausted. But how many photographs, postcards, paintings, and awestruck 'sightings' of the Grand Canyon will it take to exhaust its value as a landscape?" (2002b, 15). 
amount of money beyond their reach in a short amount of time, meet accidentally to see the demolition of a giant chimney, a part of a disused factory which, next to the dense housing of Upper Silesian towns, had thus far provided a background to people's struggle with their grim realities. The spectacular blowing-up of the postindustrial ruins acquires a symbolic dimension and may be interpreted as a harbinger of change in the lives of the protagonists, which consists in accepting the obstacles they have to face. The demolition of the factory chimney, a legacy of the region's past, hints at the possibility of a new beginning, at least in the individual lives of the characters who inhabit it. The disposal of the industrial heritage brings hope of turning over a new leaf.

Co słonko widziało is Rosa's second "Silesian" film. His 1993 television film entitled Goracy czwartek (Hot Thursday), which won him Bronze Lions for the best debut at the Polish Film Festival in Gdynia, also tells a story set thoroughly in the depressing mundanity of young inhabitants in a post-industrial city. The three protagonists are teenage Adam, Siwy, and Dworaczek, all from a poor, workingclass background. The boys strive to improve their lot, but they do not always opt for lawful means of doing so. One day, they steal a number of petty items from a car parked near a mine. The theft enables them to experience brief moments of joy, but ultimately leads to problems and disappointments. In his study of Silesian cinema, Jan F. Lewandowski noted that by setting Goracy czwartek in a region ravaged by industrial exploitation and using recurring, vivid shots of the protagonists against the background of the deformed Upper Silesian landscape with its miners' houses and slag heaps, Rosa initiated a certain trend. Lewandowski observed in the introduction to his book that many authors followed it, telling all kinds of stories in the degraded Upper Silesian scenery. He noticed that some took the bleak convention to the extremes (Lewandowski 2012, 13).

Although at first the researcher did not elaborate on the observation and refrained from mentioning the names of the directors in question, it is not difficult to identify which motion pictures he might have had in mind, especially given that they were included on his list of region-themed films spanning the period from 1920 to 2011. The first decade of the 21st century saw plenty of productions set in the distinctively visible scenery of Upper Silesia, which addressed the most topical social and economic themes at the time. In this context, one should cite such features as Oda do radości (Ode to Joy) directed by Anna Kazejak, Jan Komasa, and Maciej Migas in 2005, with particular emphasis on Ślask (Silesia), the short made by Kazejak; Z odzysku (Retrieval) directed by Sławomir Fabicki in 2006; Moje Miasto (My Town) directed by Marek Lechki in 2007; Ewa (Eve) directed by Adam Sikora and Ingmar Villqist in 2010; or Benek directed by Robert Gliński in 2007. The films usually bear the hallmarks of two genre conventions: social drama or tragicomedy. The post-transformation landscapes of the region, grimy and ugly, serve as both a setting and a complement to the fates of characters who, more often than not, 
are burdened by determinism and head towards disaster rather than culminating in a happy end. In the social dramas, Upper Silesian landscapes endow the stories with an even more depressing quality and exacerbate the sense of alienation of individuals, while the cinematic world around appears dehumanized (as in a scene in Ewa showing the protagonist, Giza, come back home through the fog-enveloped, deserted streets of a workers' colony after she fell victim to a violent assault). In the tragicomedies, landscapes may generate humor (for instance in Benek, whose protagonists set up a makeshift private mine and call it Coal Valley). Grzegorz Lewandowski's 2006 thriller Hiena (Hyena) is an exception in that respect. The scenery of disused mines, illegal coal pits, and workers' housing estates was used there as a means of artistic expression, with which the director sought to build an atmosphere of dread. However, regardless of the genre standards on which the films set in Upper Silesia draw, the leitmotiv remains the same: themes of unemployment, poverty, resultant frustration, or lack of perspectives for a better future. After her husband is laid off from the mine and suffers an accident while mining illegally, Eve's Giza decides to work at an escort agency to improve the family's dire situation. The protagonist of Benek, also a former miner, tries to find employment as a seasonal worker, butcher, even a male prostitute, but he is turned down everywhere. The family of the boy in Hiena sinks into poverty when his father dies in a mining disaster. One could even hazard the claim that motion pictures which appear to subscribe to the trend inaugurated by Rosa's Goracy czwartek have played a role in consolidating conventional iconography of the aforementioned social-economic issues, as well as established a repertoire of iconic representations of the region.

\section{2.}

The role of popular culture and the film industry in reproducing certain iconic, particularly privileged types of landscape was discussed by Tim Edensor in his National Identity, Popular Culture and Everyday Life (2002). He focused on rural landscapes, which in his opinion constitute a universally intelligible "selective shorthand" with respect to the nations which inhabit it: "Ireland has become synonymous with its West Coast .... Argentina is inevitably linked with images of the pampas .... Morocco is associated with palm trees, oases and shapely dunescapes, and the Netherlands with a flat patchwork of polders and drainage ditches. Of course, the deserts, swamps and mountains of Argentina tend to be overlooked, as do the highlands of Morocco and Holland" (Edensor 2002, 39).

If one attempted to identify that kind of representative space with a powerful symbolic and affective load in Poland, then such icons of Polishness as wayside crosses, fields of corn, haystacks, and sacred or manorial architecture would undoubtedly have to be considered. These were immortalized in a series of guides entitled Cuda 
Polski (Wonders of Poland) by Jan Buthak, the originator of the concept of "homeland photography," which took handfuls of inspiration from Romantic literature and landscape painting (e.g., Ferdynand Ruszczyc) (Rybicka 2015, 13-30). According to Edensor, sights of that type, constructed on the basis of synecdoche, are a conduit for and assure the continuity of a conservative version of national identity, where the rusticity of landscape "most frequently encapsulates the genius loci of the nation, the place from which we have sprung, where our essential national spirit resides" (Edensor 2002, 40). Thus, rural landscapes stem from national landscape ideologies which strive to create a space purified of all visual signs of strangeness or otherness. That which is different-persons, traces in architecture, cult sites, manifestations of modernity-fluctuates between hypervisibility and invisibility, Edensor argues. Set against a representative rural landscape, it is flagrantly "out of place" and therefore tends to be omitted in official presentations of national geography, vanishing from sight in a sense.

In light of Edensor's concept, the post-industrial landscapes of Upper Silesiaantithetical to ruralness and an embodiment of the otherness eschewed by national ideology-should either remain invisible or pose an apparent threat to the hegemonic vision of the Polish landscape. Still, one can hardly assert that the post-transformation depictions of the region are to be found on the margins of visibility, if they are so readily reproduced via popular culture, or that they harbor any grassroots subversive potential, since they do not demand revision of the most iconic and representative form of the national landscape. It would therefore seem legitimate to claim that the case of Upper Silesia exposes a blind spot in Edensor's theory, demonstrating that in spite of his premises the ascendancy of landscape does not consist in omitting those types of spaces which do not meet the requirements of "purified" space, in pushing them to the sidelines, introducing censorship, or prohibiting one from looking at them. On the contrary, they are made visible albeit in a particular, regulated manner which in certain respects bears paradoxical resemblance to Edensor's mechanism of "selective shorthand," but it does not come down to that. For a closer examination of the process that yields the Upper Silesian landscape, one should employ more suitable tools-namely, those provided by the concepts of W.J.T. Mitchell.

\section{3.}

In the introductory chapter to the collective monograph entitled Landscape and Power (2002), Mitchell underlined that the notion of landscape should be conceived of as a verb rather than a noun: instead of speaking exclusively of "landscape," as an object, one should also discuss it as a process. The researcher was interested in "ask[ing] not just what landscape 'is' or 'means' but what it does, how it works as a cultural practice" (Mitchell 2002a, 1). Such an approach implies relinquishing 
the conviction that landscape can be defined only through reference to the genre of modern European painting or a particular specimen of the genre. Mitchell prefers to describe it in the categories of medium, which affects the shape of particular specimens, being reciprocally influenced and molded by such specimens. Construed as a medium, landscape also functions as an intermediary in communication or exchange of various meanings and values whilst being their material vehicle; it is a reservoir of symbolic forms, which may be quoted or transformed in order to convey particular meanings (Mitchell 2002b, 14-15).

Drawing on Mitchell's idea, I would like to describe "landscaping" 3 as a mode of looking which, utilizing aestheticization, isolates a fragment of reality and shapes it into a pretense of completeness, framing views in such a way that at first glance nothing seems missing or, to use Edensor's language, operates through synecdoche to effect a "selective shorthand." In the case of Upper Silesian landscapes, the frame mainly comprises the spaces of abandoned mines, the headframes, the slag heaps, the dilapidated walls of houses, or the chimneys and crumbling structures of defunct factories, in short the derelict elements of post-industrial architecture which, by virtue of pars pro toto, begin to stand for the entire region. Following the analysis of such films as Goracy czwartek or Co słonko widziało, as well as other pictures which iterate the manner seen first in Rosa's film, one can also conclude that the sights of Upper Silesia are simultaneously encumbered with negatively connoted symbolic meanings, persistently signifying a conglomerate of facts and contents that could be branded with a joint label of "adverse aftermath of economic transformation." The effect is generated via a mechanism resembling metonymy as the meaning of landscape is constituted based on the rule of contiguity: Postindustrial ruins become signs of degradation and poverty resulting from the transformation, because the stories unfolding in that setting are concerned precisely with such issues.

According to Mitchell, landscapes camouflage exclusions and afford an ostensibly objective point of view. The views captured are naturalized and therefore seem "given" and "inevitable." Thus, inquiry into the substance and the form of each creation that exploits the medium of landscape should be accompanied by consideration of the mode and function of their cultural impact. Having applied the procedure in the analysis of Upper Silesian landscapes, it turns out that their representations in film render the space of the region homogeneous and preclude its diversity (natural, architectural, or cultural) from being seen. What is more, landscaping becomes a figure of the gaze that projects otherness and backwardness,

3 Although Mitchell underlines that the notion of landscape should be conceived of as a verb and discussed as a process, he doesn't use the word "landscaping" himself. Nevertheless, in this paper I would like to take his suggestion very literally and apply that term here. In English "landscaping" refers primarily to landscape design and signifies an action of modifying the visible features of an area of land, such as plants or landforms. I believe that the superficiality and anesthetization it connotes strongly correspond with the nature of the mechanisms that are being discussed in the article. 
thus reinforcing the image of Upper Silesia as a place which suffered particular harm during the economic shift from centrally planned economy to free market economy and now remains stuck in permanent stagnation. As it follows from my deliberations so far, works of film art do contribute to the consolidation of that image, which among other things is bolstered by their narrative characteristics, but I believe that photography plays an equally important role in that process. Post-industrial landscapes have become an object of interest for such artists as Michał Cała, Arkadiusz Gola, and Piotr Szymon, but I would like to take a closer look at the photographs by Wojciech Wilczyk, collected in the series Czarno-bialy Slack (Black and White Silesia), which is likely to have been reproduced the most and therefore remains the most recognizable.

\section{4.}

The series entitled Czarno-biały Ślask, on which the artist worked from 1999 to 2003, comprises photographs which capture the advancing decay of closed mines, industrial plants as well as factory housing estates in several towns in the Upper Silesian conurbation: Bytom, Katowice, Zabrze, Chorzów, Gliwice, Ruda Śląska, and Siemianowice. The project was neither the first nor the last of Wilczyk's encounters with the region and its architecture. Previously, between 1992 and 1996, Wilczyk witnessed the dismantling of the coking plant "Walenty" in Ruda Śląska (Pejzaż Symboliczny [Symbolic Landscape]) and from 2003 to 2006 documented the ruins of inactive industrial facilities in Poland and Germany (Postindustrial). The latter title was used for the exhibition held in 2004 at the Zderzak Gallery in Kraków, which showed images from Black and White Silesia. An album was published to accompany the show, featuring 89 photographs and essays by Andrzej Stasiuk, Wojciech Wilczyk, and Marek Grygiel (Wilczyk 2004). In my analysis, I will refer to the photographs in that very album.

Wilczyk admits that when developing Czarno-bialy Slask as well as during his earlier project at the "Walenty" coking plant he was not aware of the oeuvre of Bernd and Hilla Becher, representatives of the Düsseldorf school of photography (Wilczyk 2013, 34-37), but situating his work in the context of their achievement seems nonetheless warranted. However, what they have in common is not their "taxonomic" approach intended to capture seriality, but Wilczyk's characteristic fascinationapparently shared with the authors of Typologies of Industrial Buildings-with architectural forms that begin to resemble "post-industrial sculptures" of concrete and steel once their demolition has started. This fascination is tangible in almost all of his photographs, but it is most conspicuous in several specific instances: the view of the carbide plant in Bobrek, a borough of Bytom; the coking plant at the "Gliwice" coal mine; or the zinc galvanizing facility at the "Silesia" metalworks in the Katowice neighborhood of Wełnowiec. 
The structure of the first has been only partially demolished (or rather fell apart) at its bottom section; the upper stories have been disrupted only slightly, so the colossus stands on several steel (or ferroconcrete) legs, virtually defying the laws of physics. The coking plant in Gliwice also gives the impression of being on the brink of sinking into the abyss of the grey terrain; it leans sideways because the ground must have subsided there. Consequently, it resembles a giant cardboard box or wooden crate. In contrast, the disintegration of the zinc plant in Katowice has progressed so far that only its skeleton can be seen, a cage of steel bars, pillars and remnants of walls, which Wilczyk captured in accordance with the principles of linear perspective-with the vanishing point at the very center. The remaining photographs in the series also give the impression of a certain regularity or proportionality, as Wilczyk readily employs horizontal, symmetrical divisions in that he tries to capture reflections of the industrial features, often on the surface of puddles forming in the hollows in the ground.

Suitable framing serves to capture the architectural forms, highlighting the geometric composition of particular elements of the "post-industrial sculpture" and underscoring its monumental quality. In the essay included in the album published by Zderzak Gallery, Wilczyk often mentions looking for an apposite perspective to take his pictures (Wilczyk 2004, 11); he would come closer to and move away from the photographed feature, constantly altering the viewpoint in search of compelling frames (Wilczyk 2004, 8). However, the movement was not recorded or even signaled in any photograph, as all of them are static, immobile, with horizontal and vertical elements predominating in the composition. In an interview several years later, the artist admitted "given that a photograph crops out elements from the context, the proportions can be disrupted to some extent. My photographs ... were taken using a shift lens, which makes it possible to realign the optical axis. I would stand close to the feature and shift the lens, in other words change the proportions of the frame in a sense, thanks to which the photographed motifs appear to be more monumental than they actually are" (Wilczyk 2013, 37).

The change of proportions to which Wilczyk refers is discernible in the sets of photographs depicting a structure from several angles, as with the aforesaid coking plant at the "Gliwice" coal mine. The buildings captured in successive images are enormous, overwhelming, and therefore inhuman in a sense. On top of that, Wilczyk decided to shoot in winter and autumn, when light does not allow sharp contrasts to be brought out; it is diffused while the occasional mists add an aura of mystery and bone-chilling awe. The monochrome only boosts the effect with its halftones and a broad range of greys. If there had been some vegetation among the industrial ruins, it either remains invisible in Wilczyk's photographs, blending in with other elements of the composition, or becomes conspicuously strange, unfriendly, and sinister. Interestingly enough, although the series is titled Czarno-biały Ślask 
there is little white in the photographs; even the snow and the sky seem grey and grubby.

\section{5.}

In his inspiring Waste Matter - the Debris of Industrial Ruins and the Disordering of the Material World (2005), Tim Edensor drew attention to the difference that distinguishes between historical ruins, which are tended to, often visited by tourists and, at least since the Romantic period, looked upon with a melancholic gaze, and post-industrial ruins (Edensor 2005, 323-24). In his opinion, the latter harbor a latent subversive force: being contemporary remnants of accelerated industrialization, post-industrial ruins function on the fringe of the world we inhabit and undermine the established social order sustained by a predictable and regular distribution of objects in space. They disrupt networks composed of objects, people, places, knowledge, and relations; networks that offer stability to reality. According to Edensor, post-industrial ruins resist straightforward classifications not only because existing aesthetic codes do not apply in their case, but also because their obstinate persistence invalidates clear divisions into what has already become a piece of rubbish, a wreck, or waste and what has not; the division into the material and the no-longer material, the organic and the inorganic, is anything but clear there. Abandoned and left to their own devices, the buildings of disused factories-once a domain of what is human (social, cultural) - now blur the memory of their former functions and participate in the process of hybridization, becoming increasingly interwoven with the non-human subjects which inhabit them, such as animals or plants (Edensor 2005, 320-22).

The spaces captured in Wilczyk's photographs and the ruins analyzed by Edensor are stripped of their previous meanings: their functions are no longer intelligible due to advancing disintegration, but also because their portrayal seeks to accentuate the geometric shapes of the erstwhile industrial facilities, which hampers identification of their past meaning and renders them abstract to some degree. The analogies end there, however, as the manner in which the post-industrial relics were presented in Czarno-bialy Ślask suppresses the subversive potential mentioned by Edensor. Wilczyk appears to side with order: the frames are carefully composed following the rules of symmetry, and buildings are consistently photographed from a distance which, in conjunction with the lack of color, causes the traces of intervention of non-human life forms into their structure to be no longer perceptible. For Wilczyk, nature not so much coalesces with the cultural, challenging this binarity through hybrids, but assumes the form of a hostile force which is external to the products of culture. Its potency does not stem from vitality or exuberant creative energy but, on the contrary, from somber lifelessness that carries the threat of annihilation. Perspective also plays a substantial role in the series: the shift of the optical axis to make the structures appear particularly imposing causes them to 
outgrow any human scale by virtue of their monumentality and to acquire a stately or majestic aspect. Thus, one could hardly say that the photographs in Czarnobiały Slask created an opportunity for a new aesthetic to emerge, the aesthetic postulated by Edensor, provoking speculation on such modes of interpreting, experiencing, and imagining materiality that would transcend the obvious orders of the world we inhabit, and in consequence enable different visions of arrangement of the social reality to come forth (Edensor 2005, 330). Instead, Wilczyk exploits existing codes, granting post-industrial ruins a moment of aesthetic being: he applies brooding tonalities, engenders a kind of remoteness that triggers that mysterious effect, and uses means to make the depicted landscapes look baleful, inaccessible, and mighty at the same time. In short, Wilczyk's photographs evoke the sensation of sublimity.

\section{6.}

Those who have embarked on interpretations of Czarno-biały Ślask have often drawn attention to the documentary aspect of photographs, affirming that they represent an objective record. This conviction is conveyed in one of the essays in the album published by Zderzak Gallery, in which art historian and curator Marek Grygiel discussed Wilczyk's work using such expressions as "devoid of embellishments," "unadulterated record," and "maximum objectivity," even though he noted that each composition was meticulously planned (Grygiel 2004, 13-15). The dangers of limiting the interpretation of the series to documentary qualities have been addressed by Maria Popczyk, according to whom, by treating an image as a document, we make it a witness in an important cause at the expense of artistic value. Popczyk writes that we demand too much; we want an image to be a piece of evidence, though it can never truly be one (Popczyk 2014, 63). Still, she notes that the opposite extreme incurs a risk too, as in treating an image solely as an illusion and turning it into an aesthetic artefact, where its role is belittled, pushed aside, or even rejected, and thus fails to be introduced into the circuit of history. Such an image is additionally burdened with suspicion of manipulation (Popczyk 2014, 63). Popczyk declared herself to be an adherent of an approach that recognizes the dual nature of photography, whose output needs to be conceived as a document and a work of art that possesses artistic value, as only such a perspective makes it possible to reveal its critical dimension.

In my deliberations, I would like to avoid the risks and interpretive dead ends that Popczyk warns against. I do not consider Wilczyk's photographs to be documents that deliver unequivocal truths about Upper Silesia or, conversely, that they distort the picture of the region or create its illusion by employing particular conventions, aesthetic codes, or other devices. I would rather be inclined to claim that photographs are something between an objective record or imprint of reality and 
an artistic creation or subjective expression of a vision entertained by the subject who presses the shutter release. Alternatively, they are one and the other simultaneously, while attempts to analyze them in the categories of truth and falsity may yield much less compelling outcomes than answering how they exert their effect: how they construct the social or what their political consequences are. In my opinion, using elements of existing codes, Wilczyk casts and immobilizes suitably cropped fragments of the regional landscape in the role of objects of aesthetic contemplation. His artistic devices contribute to the consolidation of the image of Upper Silesia as a barren land whose heyday has long since passed; the landscape captured in the photographs, represented by views of post-industrial ruins, is not unlike a moonscape, a designation it may be deemed to deserve. In this respect, the photographs are in consonance with the sights reproduced in films: their details fit well into the depictions known from works by Rosa and others who continued in that particular stylistic vein. Together, they partake in the landscaping of Upper Silesia, a process which consists in exposing those areas that fail to meet the requirements of "purified space." One could therefore say that they become instruments of epistemological conquest of sites that are different or peripheral with regard to the most privileged types of national landscape. The case of Upper Silesia seems to corroborate Mitchell's diagnosis, namely that landscape today is an "exhausted' medium, at least for the purposes of serious art or self-critical representation" (Mitchell 2002b, 5). Are there really no tools with which one could transcend the dominant mode of constructing and perceiving the views of Upper Silesia?

\section{7.}

Under the assumption that the above representations of Upper Silesian landscape are indeed iconic in nature, both in terms of semiotics, as they come into being through synecdoche and-perforce-have to resemble the referent, and in popular understanding, meaning that they are exceptionally recognizable; in this light, the culminating sequence in Rosa's film with which this analysis began seems an act of iconoclasm. As already observed, the demolition of the ruins of a disused factory may be interpreted as a symbolic token of change in the lives of the protagonists of Co stonko widziało, but it may equally well be only a chimera of a fresh start: the chimney towering over the town is a legacy of the region's past, but its destruction will have no retrograde effect on that past, which after all has shaped the circumstances in which Rosa's characters live. Getting rid of an inconvenient image-a visible testimony to a particular method of arranging the visual field-does not abrogate the rules which govern the arrangement. Furthermore, one of the properties of iconoclastic gesture is that it tends to multiply the old 
and create new images rather than dispose of any for good. ${ }^{4}$ This is evidenced in the proliferation of representations which iterate the depiction of a degraded and backward Upper Silesia, and in the rise of shopping centers and glass-covered towers where mines had once been, where the new structures have identical equivalents throughout Poland. Shattering the icon is not a condition which, if met, will enable insights into the diversity of Upper Silesia, become a point of departure for a critical reflection on its place in the national imaginary, or create possibilities for articulating regional identity from a more agential position. I believe that the only means of neutralizing the incapacitating outcomes of Upper Silesian "landscaping" may be found in such uses of landscape forms which go against Mitchell's assertion, which adopt a change of viewpoint, a realignment, an adjustment of distance as pre-requisites of apprehension, reflection, and action. In other words, they reformulate the rules governing the visual field from within the latter. Searching for and explaining the dynamics which drive such representations is a project worthy of undertaking by landscape and visual culture researchers.

\section{Bibliography:}

Edensor, Tim. 2002. National Identity, Popular Culture and Everyday Life. Oxford: Berg.

Edensor, Tim. 2005. "Waste Matter — the Debris of Industrial Ruins and the Disordering of the Material World." Journal of Material Culture 10 (3): 311-32

Frydryczak, Beata. 2013. Krajobraz. Od estetyki picturesque do doświadczenia topograficznego [Landscape: From the Aesthetics of the "Picturesque" to Topographic Experience]. Poznań: Wydawnictwo Poznańskiego Towarzystwa Przyjaciół Nauk.

Grygiel, Marek. 2004. "Chłodnym okiem" ["With a Cool Gaze"]. In Czarno-biały Śląsk [Black and White

Silesia], 13-15. Kraków: Galeria Zderzak—Górnośląskie Centrum Kultury Lewandowski, Jan F. 2012. Kino śląskie [Silesian Cinema]. Katowice: Śląsk.

Mitchell, William J.T. 2002a. "Introduction." In Landscape and Power, edited by William J.T. Mitchell, 1-4. Chicago: The University of Chicago Press

Mitchell, William J.T. 2002b. "Imperial Landscape." In Landscape and Power, edited by William J.T. Mitchell, 5-34. Chicago: The University of Chicago Press.

Popczyk, Maria. 2014. "Krajobraz jako obraz" ["Landscape as Painting"]. In Krajobraz kulturowy [Cultural Landscape], edited by Beata Frydryczak and Mieszko Ciesielski, 55-64. Poznań: Wydawnictwo Poznańskiego Towarzystwa Przyjaciół Nauk.

Rybicka, Elżbieta. 2015. "Relacje centro-peryferyjne a polityka konstruowania tożsamości regionalnej" ["Center-periphery Relations and Politics Built on Regional Identity"]. In Centra-peryferie w literaturze polskiej XX i XXI wieku [Centers and Peripheries in Polish Literature of the 20th and 21st Centuries], edited by Wojciech Browarny, Elżbieta Rybicka, and Dobrawa Lisak-Gębala, 13-30. Kraków: Universitas.

4 The efficacy of the iconoclastic gesture-among other things-was compellingly discussed by Zaremba (2014a). 
Salwa, Mateusz. 2014. "Krajobraz jako doświadczenie estetyczne" ["Landscape as Aesthetic Experience"]. In Krajobraz kulturowy [Cultural Landscape], edited by Beata Frydryczak and Mieszko Ciesielski, 4354. Poznań: Wydawnictwo Poznańskiego Towarzystwa Przyjaciół Nauk.

Wilczyk, Wojciech, 2004. Czarno-biaty Śląsk [Black and White Silesia]. In Czarno-biaty Śląsk [Black and White Silesia], 7-12. Kraków: Galeria Zderzak—Górnośląskie Centrum Kultury.

Wilczyk, Wojciech. 2013. "Wszystko monumentalnie podupada" ["Everything Monumentally Deteriorates"]. By Katarzyna Mrugała. Autoportret 1 (40): 34-44.

Wylie, John. 2007. Landscape. London: Routledge.

Zaremba, Łukasz. 2014a. "Męki obrazów" ["The Suffering of Paintings"]. Widok. Teorie i praktyki kultury wizualnej 5. http://pismowidok.org/index.php/one/article/view/169/284.

Zaremba, Łukasz. 2014b. "Polobrazy, krajobraz i to, co wspólne" ["Polobrazy, Landscape, and Their Commonalities"]. Widok. Teorie i praktyki kultury wizualnej 8. http://pismowidok.org/index.php/one/ article/view/266/469. 